NBER WORKING PAPER SERIES

WORKER NEEDS AND VOICE IN THE US AND THE UK

\author{
Alex Bryson \\ Richard B. Freeman \\ Working Paper 12310 \\ http://www.nber.org/papers/w12310 \\ NATIONAL BUREAU OF ECONOMIC RESEARCH \\ 1050 Massachusetts Avenue \\ Cambridge, MA 02138 \\ June 2006
}

We would like to thank participants at the 2005 SOLE in San Francisco and seminars at Cornell ILR, Dartmouth, the University of Michigan, and the University of South Carolina for comments on earlier versions of this paper. We acknowledge the Department of Trade and Industry, Acas, the Economic and Social Research Council and the Policy Studies Institute as originators of the WERS data and the Data Archive at the University of Essex as the distributors of the data. Alex Bryson thanks NBER and Harvard Law School for financial support. The views expressed herein are those of the author(s) and do not necessarily reflect the views of the National Bureau of Economic Research.

(C2006 by Alex Bryson and Richard B. Freeman. All rights reserved. Short sections of text, not to exceed two paragraphs, may be quoted without explicit permission provided that full credit, including $\odot$ notice, is given to the source. 
Worker Needs and Voice in the US and the UK

Alex Bryson and Richard B. Freeman

NBER Working Paper No. 12310

June 2006

JEL No.

\begin{abstract}
$\underline{\text { ABSTRACT }}$
Workers have responded differently to declining union density in the US and UK. US workers have unfilled demand for unions whereas many UK workers free-ride at unionized workplaces. To explain this difference, we create a scalar measure of worker needs for representation and relate desire for unionism to this measure and to the choices that the US and UK labor relations systems offer workers. Our measure of needs has similar properties across countries and is the single most important determinant of worker desire for unions and collective representation. Conditional on needs, we find that in both countries workers are more favourable to unions when management is positive toward unions, but also favor them when management strongly opposes unionism, compared to management having a neutral view. Much of the difference in the response of US and UK workers to declining unionism appears to be due to the different institutional arrangements for voice that the countries offer to workers.
\end{abstract}

\author{
Alex Bryson \\ Principal Research Fellow \\ Policy Studies Institute \\ 50 Hanson Street \\ London W1W 6UP \\ UNITED KINGDOM \\ a.bryson@psi.org.uk \\ Richard B. Freeman \\ National Bureau of Economic Research \\ 1050 Massachusetts Avenue \\ Cambridge, MA 02138-5398 \\ freeman@nber.org
}


Membership in trade unions has fallen in the US and UK, creating a potential gap between the representation and participation workers want and the voice they get at their workplace. Workers have responded to declining unionization in the two countries differently. In the US a large proportion of non-union workers want union representation, which they cannot obtain. In the UK a large proportion of workers free ride at sites where employers recognize unions.

What explains the difference in worker responses to falling unionism in the two countries? Do UK and US workers respond differently because they have different needs for representation or because the two countries offer different menus of options to meet those needs?

We use data from the US's Workplace Representation and Participation Survey (Freeman and Rogers, 1999) and the comparable British Workplace Representation and Participation Survey (Diamond and Freeman, 2002), and from the UK's Workplace Employment Relations Survey (Cully et al., 1999) to examine these questions. ${ }^{1}$ We generate a single scalar variable - needs for representation - to measure the likely factors that lead workers to seek collective voice and examine its determinants and relation to the desire for union representation. We find that the distributions of workers' perceived needs for representation are similar in the two countries and are the chief determinant of desire for union representation. We attribute US-UK differences in worker desires for different forms of voice to differences in the institutional choices on offer in the countries rather than to differences in needs or in attitudes toward collective or individual solutions to problems.

\section{Unionisation and worker attitudes}

To begin with, union density has fallen in both countries. Density in the US fell from the mid-1950s through the mid-2000s to reach $12.5 \%$ overall and $7.9 \%$ in the private sector in 2005 despite the organization of public sector workers in the 1960s (BLS, 2006). Density in the UK rose in the 1970s and then fell in the 1980s and 1990s, largely in the private sector, before stabilizing at $29 \%$ of all employees and 17\% of employees in the private sector in 2005 (Grainger, 2006).

\footnotetext{
${ }^{1}$ These data sets are described in Appendix A.
} 
The US response to declining union density shows up in high levels of unfilled demand for unionism. The standard measure of unfilled demand is the proportion of non-union workers who say they would vote for a union in an NLRB representation election. Freeman and Rogers' WRPS found that $32 \%$ of non-union workers in private sector workplaces with over 25 employees would vote for union representation but did not have it in 1994-95. Lipset and Meltz's Angus Reid survey reported that $16 \%$ of US workers would definitely vote union and that $32 \%$ would probably vote union, giving $48 \%$ support for unionism, in $1996 .{ }^{2}$ More recent data from Peter D. Hart Research Associates shows a rising trend in the proportion of workers who say they would vote in an NLRB election from 1993 to 2005 (Figure 1) to exceed 50\% in 2003 and 2005. ${ }^{3}$ The upward trend runs against explanations of declining union density in terms of falling worker interest in unions. ${ }^{4}$

As for the UK, the BWRPS asked workers at workplaces without union recognition the likely effect a union would have on conditions at the site. Sixty six percent of respondents reported that they thought a union would not affect anything; while $22 \%$ thought the workplace would be better with unions and 13\% thought it would be worse. The BWRPS also asked non-union workers in non-union workplaces: 'If a group of workers at your workplace formed a union and asked you to join, how likely is it that you would join that union?' Sixteen per cent said it was 'very likely' they would join, while 30 per cent said 'quite likely'. If we define British workers wanting a union as those who report that they are 'very likely' to join and who believe a union would make their workplace better, just $10 \%$ of non-union employees in non-union UK workplaces would be

2 The unfilled demand for unionism in the US exceeds the comparably defined level in Canada and estimates of the desire for unions in other English-speaking countries. See Lipset and Meltz (2004) for Canada and Boxall, Freeman and Haynes (2006) for other countries

${ }^{3}$ A 2005 Zogby poll reported a lower rate of workers seeking unionism than the Hart survey: 35\% would vote union (http://www.zogby.com/news/ReadNews.dbm?ID=1011). This is below the $45 \%$ Zogby reported as wanting to join in 2004, but still higher than the WRPS estimate for 1995.

${ }^{4}$ Farber and Krueger (1992) argued that falling interest in unions contributed to the decline in density. If desire for unionisation is constant, declines in density should raise the proportion of non-organized workers who want unionism. Since the percentage of non-union workers saying they would vote union was roughly constant in the period they examined, they attributed some of the decline to loss of interest in unions. The Hart Poll increase in the proportion saying they would vote union runs against this story. 
classified as wanting unionisation. ${ }^{5}$ In fact, rather than joining unions when they can, British workers have increasingly chosen to free ride at workplaces with recognized unions.

The end of the closed shop in the early 1990s gave British workers in unionised establishments the choice to join or not at unionised workplaces. Figure 2 shows that the proportion that chose to free ride increased greatly from the 1980s to the 1990s. The WERS establishment data shows a doubling in the rate of free riding from 1980 to 1998 . The British Social Attitudes Survey shows a large rise in free riding from 1983-85 to 1999-2001. Shift-share analysis suggests that around 10 percentage points of the $12-13$ percentage point decline in mean union density in unionised workplaces between 1990 and 1998 is due to "a reduced propensity among employees to join trade unions, even when encouraged to do so [by management]" (Millward et al. 2000: 149-151). ${ }^{6} \quad$ British trades unions refer to the problem of enlisting workers in organized workplaces as the "in-fill problem" since it involves filling membership at sites where the employer recognizes the union and may even encourage workers to join. ${ }^{7}$

The free rider behaviour of UK workers exceeds that of US workers in right to work states, where workers can choose to free ride as well but where $90 \%$ join the union (Farber and Western, 2000). As Figure 2 shows, 9 per cent of covered workers in the US were non-members in 2005, declining marginally since the early 1980 s due to a fall in free-riding in the public sector.

\section{Workplace Needs or Problems as Determinants of What Workers Want}

To understand why American workers have huge unfilled demand for unionism while British workers increasingly free ride at workplaces where the firm recognizes unions, we analyze

\footnotetext{
${ }^{5}$ The 1998 British Social Attitudes Survey asked nonunion workers at nonunion workplaces if there were a trade union at the workplace the likelihood they would join: 15 per cent said they would be 'very likely' to join, and 24 per cent said 'quite likely'.

${ }^{6}$ Management respondents attributed declining union membership in their workplace during the 1990s mainly to a decline in employee support for their union (Millward et al., 2000: 92). Blanchflower (2006) presents European Social Survey 2002/2003 data that British workers are among those in Europe least likely to agree that "Employees need strong trade unions to protect their working conditions and wages". ${ }^{7}$ Consistent with this, BSAS data for 1983-2002 show that among workers in unionized workplaces the probability of having once been a member and no longer one rose from 15-17 per cent of the 'evermember' pool through 1993 to 21-22 per cent since 1995.
} 
how workplace problems affect worker desires for collective voice. We assume at the outset that labor problems arise naturally at all workplaces. Management makes errors, workers and management differ in information and perspectives and disagree about the division of rewards. Some of the problems are collective in nature and may impel workers to look to unions or other employee groups for resolution. Other problems are individual, which affect workers singly and which are less likely to lead them to look for collective solutions.

All the micro-data sets we examine asked employees about particular problems at their workplace and about their workplace's general climate. The WRPS and BWRPS also asked about the influence workers had and wanted in different workplace decisions, and the grades workers give to management in dealing with workplace issues. To compare the reported needs across different questions and surveys, we developed a NEEDS scalar measure, using a scale from 0 to 1 . We coded responses to questions relating to needs for representation as $0 / 1$ variables, where 0 means no problem/need and 1 means a problem/need. We then summed these measures to obtain the total number of needs and divided the sum by the total number of questions, to obtain the fraction of needs reported, relative to the maximum possible in the survey. This approach facilitates comparisons of the reported needs across the different questions and surveys.

We illustrate how we measure needs with the BWRPS. The influence questions asked how much influence workers wanted in an area and how much influence they had. We coded workers as having a problem when they said they wanted a lot of influence in an area and did not have it. British workers had problems in determining pay raises and perks and bonuses - traditional trade union domains (Diamond and Freeman, 2002). The grade question on the BWRPS asked workers to grade management with a school grade scale from $\mathrm{A}$ to $\mathrm{F}$. We coded $\mathrm{D} / \mathrm{F}$ grades as a 1 for problem or need. Few British workers give management D/F on understanding and knowledge of the business but a sizeable number gave them those grades in granting pay increases, sharing authority, and making work interesting. On the questions about unfair practices, the most common unfair practice was preferential treatment by management or senior staff; the second most common was 
payment of unfair wages; followed by unfair dismissal and discipline and bullying; discrimination was the least cited problem. Thirty-nine percent of workers cited at least one unfair practice as being a problem at their current workplace. We counted responses to questions about general workplace climate, such as trust in management, security of employment, pleasantness of jobs, and employee management relations as a problem only when workers reported it as particularly bad.

In sum, we used 26 different BWRPS items to measure problems at workplaces. Because the survey had a split sample design, however, some items were asked of only half of respondents, so that we have observations for each individual on only 23 items. We then divided the number of needs by 23, so that the NEEDS variable can vary from zero (no problems reported) through 1.0 (worker reports problems for every item they answered on the survey).

We followed a similar strategy in analyzing the 13 different WERS questions on problems/needs at the workplace. We coded responses 1 if workers reported a problem or were dissatisfied with their situation and zero otherwise. We then summed the responses and divided by 13 to form a single scale of workplace needs. The WERS scale takes the value 0 when workers report no problems and 1 when they report the maximum number of problems.

Turning to the US, the WRPS asked employees about employee needs for representation or participation in terms of the influence workers had in workplace decisions and the influence they wanted in those decisions. The difference between the influence workers had and the influence they wanted is Freeman and Rogers' (1999) representation and participation gap. When workers said that they wanted "a lot" of influence in an area and also said that they did not have "a lot" of influence, we counted this as 1 , indicating a need or problem in the area. The survey also asked about general workplace climate, trust in management, security of employment, pleasantness of jobs, and employee management relations, etc. We coded responses to each relevant question as 1 if the worker had a need/problem and 0 otherwise. Given the split sample design of the survey, each worker on the WRPS answered 13 questions about needs. From these data, we constructed a needs measure that varied from zero (no needs) to 1 (all 13 items coded as 1 in terms of needs). 
In sum, for all of our data sets we computed a new variable Workplace Needs, which we treat as the primitive factor likely to create desire for collective voice. ${ }^{8}$

\section{The distribution of needs}

Figure 3 graphs the distribution of the Workplace Needs variables from the surveys. All of the distributions have the same shape. The mode occurs at zero needs/problems and the proportion of workers reporting positive numbers of needs declines nearly monotonically. Panel A shows that in the BWRPS $23 \%$ of workers reported no needs or problems; $54 \%$ reported problems on less than three of the items, while just $23 \%$ reported problems on three or more items. As a result of this concentration, $10 \%$ of workers accounted for $52 \%$ of all the reported problems/needs. Panel B shows a comparable bunching of responses at zero followed by a declining proportion reporting higher numbers in the WERS. Finally, Panel C for the US WRPS also shows that thirty-two percent of workers report no problems while $74 \%$ report problems on less than three items.

The figure gives the mean and variance for the scalar measure of needs for each survey. The mean and variance of needs are as follows: WRPS 0.134 and 0.022; BWRPS 0.156 and 0.030; WERS 0.211 and 0.057. All three distributions diverge from the distribution of needs/problems that would be generated by a binomial distribution in which a worker had an independent random chance of reporting a problem on an item at the average rate reported in the sample. In the binomial case, there would only be a small mass at zero needs/problems, and the distribution would look more or less normal around the average rate. The variance of the distribution would be (1-P) P, where $\mathrm{P}$ is the fraction of responses that reported a workplace need, and. Instead, the distribution is shaped like a power law or exponential, ${ }^{9}$ and the variances are much larger than those from a

\footnotetext{
${ }^{8}$ Appendix B gives the questions and decision rule for each measure. An alternative approach is to use the full information in the distribution of responses on each question so that the additive scale weights responses according to how much of a problem it was. Using a simple scale with 1 to reflect the lowest possible response to problems/needs, 2 to reflect the next level, and so on, we formed a summated rating of these responses and obtained results that parallel those in the paper. ${ }^{9}$ We regressed $\ln$ (the \% reporting number of needs) on the number of needs to fit an exponential distribution and regressed $\ln$ (the $\%$ reporting number of needs) on $\ln$ (the number of needs) to fit a
} 
binomial distribution. The reason the distribution takes on the non-normal shape is simple: the needs of workers on different items are not independent. Knowing that a worker reports needs on any item gives information about their likelihood of reporting needs on other items.

There are two possible reasons for the non-independence of the reports of needs. One possibility is that it reflects workers' personal characteristics. A given worker may see more problems or get into more problems than others. In this case, the individual nature of needs is unlikely to translate into a collective response. The other possibility is that the non-independence reflects attributes of the workplace, which most workers would report. One workplace would generate many problems while another would not. The former would likely produce a general desire for representation at a workplace, while the latter would not

The BWRPS and WRPS surveys do not allow us to identify the workplace component of needs, since they do not identify workers at the same workplace. Nor do they permit identification of the individual component of needs since they do not follow workers from one workplace to another. But the WERS sample design allows us to identify the workplace component because it surveyed up to 25 employees at each of the sampled workplaces. Where the workplace had 25 or fewer workers, all employees were selected. In larger workplaces 25 workers were drawn randomly for the employee survey. The result is a data file that contains reports by different workers in the same workplace - the information necessary to identify a fixed workplace effect in needs.

\section{Needs at the same workplace}

Accordingly, we created a data file from WERS that gave the number of needs reported by 25,451 employees at 1,759 workplaces. This gave us an average of 14.5 worker reports on needs per workplace. We tabulated the needs reported by workers for each workplace and ranked the workplaces by average needs. This tabulation shows that workplaces in the upper ten percent of the distribution of needs averaged 6.23 needs on the WERS scale from 0 to 13 - giving it a needs scale

power law. The exponential fits the BWRPS and WRPS better than a power law, whereas the power law fits better for the WERS. 
measure of 0.48 -- whereas workplaces in the lower ten percent of the distribution of needs averaged 0.74 needs for a scalar measure of $0.06 .{ }^{10}$ Such wide variation by workplace makes a prima facie case that the differing labor situations at workplaces are a key factor for worker reports of problems or needs. We also compared the variance in needs explained by individuals' demographic and job characteristics with the variance explained by workplace fixed effects. As table 1 shows, the $\mathrm{R}^{2}$ is around 0.2 in models containing only workplace fixed effects and 0.1 in models containing individual and job characteristics. When the two are combined the $\mathrm{R}^{2}$ rises to around 0.25 and the workplace fixed effects remain jointly highly significant.

These data thus show that workers at a given workplace report sufficiently similar numbers of needs to identify "good" and "bad" workplaces, which in turn suggests that workers who report lots of needs are likely to seek some form of representation to redress workplace problems.

\section{Determinants of needs}

In addition to workplace factors, the demographic and economic characteristics of workers affect the number of needs that they report. To analyze these patterns, we estimated regression equations linking needs to characteristics, union membership, and selected management human resource (HR) policies in the US WRPS and UK BWRPS. Table 2 gives the regression coefficients and t-statistics for estimates of the effect of HR policies and management attitudes toward unions for all workers (column 1-2), for non-union members (column 3-4) and for union members (column 5-6). The regression models include extensive control variables as listed in the notes to the table. ${ }^{11}$

The coefficients on variables in table 2 for the two countries are qualitatively similar, suggesting that the same labor policies affect workers in the same manner, albeit with different magnitudes. Consider first the positive estimated coefficients on union members in columns 1 and 2: these estimates indicate that, all else the same, union members report more needs than non-

\footnotetext{
${ }^{10}$ Alternatively, needs averaged 1.25 at the $10^{\text {th }}$ percentile and 5.09 at the $90^{\text {th }}$ percentile.

${ }^{11}$ The control variables show that the strongest relations are for workplace factors. The number of workers in an organization and workplace are positively correlated with needs. In addition, workers with greater job tenure have higher needs than newer workers, white collar workers have fewer needs, while most other factors have modest effects on needs.
} 
members, potentially because unions seek out problems for resolution, through the voice mechanism (Freeman and Medoff, 1984). The next set of variables are human resource management policies measured as dichotomous variables: either the firm has a policy or it does not. Presence of policies reduces the number of needs substantially. An open door management system has a massive impact on needs, followed by the presence of worker committees - employee involvement committees in the US and joint consultative committees in the UK. Most of the other policy measures also reduce the number of needs, though the presence of grievance procedures in the UK raises the number of needs. The coefficients on these variables in columns 3-6 for nonunion members and members show that the policies have generally similar effects for the two groups. $^{12}$

The coefficients on the variables "management opposed to unions" and "management favorable to unions" show the impact of those attitudes, as reported by workers, compared to the reference group, where the worker judges management as indifferent or with policies the respondent does not know. Management opposition to unionism is associated with more needs, suggesting that this stance may reflect a harsh policy toward worker concerns. By contrast, management in favour of unions has a negative but non-significant effect on needs in the US and a substantial negative effect in the UK. The regressions for non-members and members in columns 3-6 show that the reduction in needs in UK firms where managements are favorable to unions occurs solely in organized workplaces.

Because the regressions are sufficiently similar in the two countries, we ran a regression for the pooled country data. In this pooled regression the dummy variable on the US is negative and significant for all workers, and for non-members and members. The implication is that conditional on all other factors, the major difference between the US and UK is that American workers have lower needs. This means that the greater desire of US non-union workers than of UK non-union workers for unions cannot be attributed to needs. To explain this difference in what workers want

\footnotetext{
12 The exceptions are profit-related pay, which has a negative effect on non-members' needs but a positive effect on members', and grievance procedures for the US which is negative for nonmembers but positive for members.
} 
in the two countries, we turn to differences in the institutions for collective voice that the two countries offer workers.

\section{Determinants of What Workers Want: Institutions On Offer}

The second part of our analysis links worker desire for unions/other forms of collective voice to the voice options available to workers. Firms affect what is available by offering nonunion channels of voice and by responding positively or negatively to worker efforts to form unions or other independent organizations. Unions affect what is available by delivering services to members at organized workplaces and by campaigning to organize workers in sites that do not have union representation/recognition. The state affects what is available by legal enactment and enforcement of labor laws. Our analysis takes the institutions on offer from employers, unions, and the state as exogenous, and thus falls short of a complete model of a labor relations system that would treat the decisions of employers, unions, and the state to offer those choices as endogenous. We begin by considering the attributes of institutions that workers want to deal with their problems and then turn to their preferences among the institutions on offer.

\section{Workplace institutions to solve problems}

The WRPS and BWRPS asked workers several questions about the types of workplace organizations they wanted to deal with problems. They asked if workers wanted groups of workers for support on workplace issues or if they preferred to deal with problems on their own. They asked about the relation they wanted any worker-based organization to have with management. The surveys have similar findings. Most workers wanted some form of organization to deal with collective goods problems at workplaces; and most wanted employee-based organizations that work cooperatively with management as opposed to those involved in continual conflict with management.

Table 3 presents the evidence for these conclusions. Panel A shows that a majority of workers in both the US and UK prefer collective solutions for problems likely to affect the entire 
work force: benefits and health and safety issues in the US case; and salary and workplace conditions in the UK case. By contrast, a majority of workers in both countries prefer to deal with career development issues by themselves: training in the US case and training and promotion in the UK case. Where US and UK workers differ is in how they want to deal with problems of protection against bad treatment at the workplace. US workers prefer to deal with unfair treatment or harassment by themselves, possibly because US employment law provides considerable legal rights to workers who face discrimination at the workplace, while UK workers prefer to have the help of fellow employees with these sorts of problems.

Panel B shows that workers in both countries prefer worker organizations with which management cooperates to organizations that conflict with management. The majority of US employees would choose a workplace organization with no power but with which management cooperates to an organization with power but which management opposes. The reason is that the majority believe that an employee organization cannot be effective without cooperation. Similarly, UK workers prefer an organization that "work(s) with management to improve the workplace and working conditions" to an organization that declares its main function as "defend(ing) workers against unfair treatment by management." They prefer this even though most union members regard defending workers against unfair treatment to be one of the principal goals of their union (Bryson, 2005). ${ }^{13}$

Given that workers in the US and UK report similar needs/problems at their workplaces and have similar preferences for dealing with workplace needs with the help of employees and through worker organizations that have cooperative relations with management, why do US workers have such a large unfilled demand for unions while UK workers increasingly free ride at workplaces with recognized unions?

\footnotetext{
${ }^{13}$ One reason for the desire for cooperative relations is that the number of workplace problems falls when management and unions work cooperatively (Bryson and Freeman, 2006).
} 
We consider next three factors likely to affect the differential response of US workers and UK workers to falling unionization.

\section{Difference in Management Policies toward Unions and Voice}

Since union premiums shift profits from shareholders to workers, it is natural for firms to seek to oppose unionism and to offer voice solutions that may substitute for unions.

Management opposition to unionisation is stronger in the US than in the UK. For the US, the WRPS finds that $53 \%$ of managers in non-union firms say they would oppose efforts by employees to unionise, $27 \%$ said they wouldn't care, and $15 \%$ said they would welcome the effort (Freeman and Rogers, 1999). Many labor-management consulting firms specialize in helping business maintain a "union-free environment" (Logan, 2002). By contrast, in the UK, most employers are neutral towards unions: $65 \%$ of non-unionised private sector employers in WERS 1998 expressed neutrality about union membership among its employees, 30\% expressed opposition and 5\% were favourable (Bryson, et al., 2004). ${ }^{14}$ An obvious reason for this difference in management attitudes is that the US union wage premium is among the highest in the world, whereas the UK premium is modest.

At the same time management in both countries have developed positive labor relations in the form of modern human resource programs that arguably could substitute for unionism. In the US Section 8(a)(2) of the US's National Labor Relations Act outlaws company sponsored systems of collective voice as company unions designed to undermine workers setting up their own organization, and thus limits management ability to develop such substitutes (LeRoy, 2006). By contrast the UK's historically voluntaristic labour-management system makes it easier to develop alternatives to unionism.

Differences in the Legal Choice Set

\footnotetext{
${ }^{14}$ Managers were asked: 'How would you describe management's general attitude towards trade union membership among employees at this establishment? Is management...in favour of trade union membership, not in favour of it, or neutral about it?'
} 
The UK and the US offer workers and management different choice sets for worker representation and participation. In addition to unions, the UK offers a range of workplace institutions including employer sponsored workplace committees. It has added works councils under the EU Social Charter. Lay representatives deliver union services at workplaces. Managerial employees as well as those without supervisory roles often join unions. ${ }^{15}$ At the end of the 1980 s the Conservative government removed legal protections from the closed shop, which allowed for the large increase in free riding. At the end of the 1990s, the Labour government introduced elections for union status when firms refused to recognize employees seeking union status, but this has been used infrequently.

The US's National Labor Relations Act offers a narrow range of choices for workers in the private sector. In principle US law protects minority unionism, but the de facto choice has been between a collective bargaining majority union and no worker organization. By posing the choice of workplace labor institutions as 0/1 union/no union, the US system stokes employer opposition to unionism and encourages firms to develop policies for individual voice, but not for collective voice.

\section{Differences in Union Effectiveness}

Another potential reason for the differing attitude of US workers and UK workers to the decline of union representation is that union effectiveness differs. The higher union wage premium in the US than in the UK (Blanchflower and Bryson, 2003, 2004) suggests that unions are more effective in delivering "monopoly" gains to members in the US. Whereas the US union wage differential remains one of the highest in the world, WERS data suggests that UK unions' efficacy has declined over the past two decades or so. Even where unions are recognised by employers for negotiation purposes, collective bargaining coverage has declined (Millward et al., 2000: 159-167), leading some commentators to the 'inescapable conclusion that workplace trade unions no longer

\footnotetext{
${ }^{15}$ In $200519 \%$ of managers and senior officials were unionised (Grainger, 2005).
} 
negotiate to any significant extent on behalf of their members' (Terry, 2004: 205). ${ }^{16}$ Neither the

WRPS nor the BWRPS ask workers in non-union workplaces about their assessment of the effectiveness of unions (on the assumption that workers in non-unionized workplaces would have limited or no knowledge of union effectiveness in unionized sites). Both do ask workers in unionised workplaces about the perceived effectiveness of unions and preferences for union representation.

In the WRPS data, $31 \%$ of US union members report that they are very satisfied with union bargaining over wages and benefits, while in the BWRPS, just $11 \%$ of union members give their union a high grade for 'winning fair pay increases and bonuses' ${ }^{17}$ But delivering on wages and benefits is not the sole purpose of unions. The WRPS shows that $30 \%$ of members thought unions were 'very effective' in resolving group problems or concerns, while a further 53\% thought they were 'somewhat effective'. Thirty-five percent of union members rated their union high in choosing local leaders democratically compared to $17 \%$ who rated their union low. The figures from analogous questions for the UK show lower assessments of effectiveness. In the BWRPS UK workers gave unions a mixed rating, giving them lower grades than management in making workplaces better in some areas (Diamond and Freeman, 2002). Only 17\% rated their union high in being open and accountable to its members and only 15\% rated their union high in sharing information. The structural features of unions (high density, on-site union representatives etc.) that are associated with perceptions of high union effectiveness are not widespread throughout the union sector (Bryson, 2005). ${ }^{18}$ In short, the evidence and responses of workers to questions about union

\footnotetext{
${ }^{16}$ On the other hand, time-series data show that a fairly constant two-thirds of unionised employees believe that 'unions do their job well' over the period 1983-2001 (Bryson and Gomez, 2002).

${ }^{17}$ The BWRPS asked British workers to grade their union on various dimensions; we coded A as high and D/F as low. The US survey asked if workers were very satisfied, satisfied, not too satisfied or not at all satisfied in an area; we coded very satisfied as high and not too or not satisfied as low. ${ }^{18}$ Supporting the notion that some of the problems faced by UK unions are associated with their lack of efficacy, Bryson and Freeman (2006) find that perceived union effectiveness is associated with fewer expressed needs and that workers are more likely to choose unions when they believe unions "make a difference to what it is like to work here" and "take notice of members' problems and complaints".
} 
effectiveness suggest that US unions are more effective than UK unions in delivering benefits to members and in accountability to them. ${ }^{19}$

Where US unions have been ineffective is in organizing the millions of workers who seek union representation in the face of company opposition. Organizing in the US has become extremely expensive, as unions and management pour resources into NLRB election campaigns. Farber and Western (2001) and Freeman and Rogers (1999) estimate that unions would have to devote the bulk of their budgets just to organize enough workers to maintain their present density with current organizing techniques and effectiveness. It is only outside the standard collective bargaining framework that unions have managed to enlist members at low cost, either through card checks $^{20}$ or through organizing workers into non-collective bargaining groups. In arguably the most successful such activity in 2005 the AFL-CIO sent organizers into ten cities to ask people to join a non-collective bargaining AFL-CIO affiliate, Working America (www.workingamerica.org). The organizers signed up 1,200,000 members by early 2006 . This is the strongest evidence we have that the survey findings that millions of non-union workers want to join a union reflects genuine attitudes, not simply casual responses to a survey.

But UK unions do not seem to be any more effective in organizing workers than US unions. Unions in the UK face serious financial difficulties, partly due to declining density, but also to other factors (Willman and Bryson, 2005). The weakness in organizing is illustrated by BWRPS evidence that over half $(56 \%)$ of non-members eligible to join the union at their workplace say they have never been asked to join by the union. Since $10 \%$ of non-members in unionised workplaces say they would be 'very likely' to join if asked, and a further $26 \%$ say they would be 'quite likely'

${ }^{19}$ Consistent with this, the positive coefficient of unionism on number of needs reported in columns 1 and 2 of table 2 is larger in the UK than in the US.

${ }^{20}$ AFL-CIO national organizing director Stewart Acuff told the Wall Street Journal in August 2005 that three times as many workers were added through "card checks" than through traditional secret ballot elections. And the Bureau of National Affairs reported in January 2006 that UNITE HERE president Bruce Raynor estimates that 90 percent of his new members had been organized through "alternative means" that avoided elections. 
to join, this is a significant missed opportunity which means demand for unionisation goes unmet.

The removal of closed shop legislation in the early 1990s heightened the problem for unions, for it allowed employees in unionised workplaces to free-ride on union-provided services, making it critical that unions offer private excludable goods to workers to induce them to join (Bryson, 2006).

\section{Workers' Choice of Workplace Institution}

The WRPS and BWRPS surveys asked several questions about workers' preferences for unions and other modes of representation and institutions of voice.

The WRPS asked US workers three questions relating to desire for unions. It asked whether they would vote for a union in a representation election. It also asked them to choose among three institutions to increase their say in workplace matters: unions (half of the sample) or an elected body of workers to bargain with management (the other half of the sample), joint employee management committees, or labor laws. Finally, it asked them separately about the characteristics of any joint committee that they might prefer, including whether there should be recourse to an outside arbitrator, whether the organization should be employee-run or run jointly with management, and whether employees should elect representatives.

The BWRPS asked UK workers three questions on the desire for unions. It asked whether they would support unions at their workplace or if their union was worth the dues they paid it; whether they thought unions would make the workplace better; and whether they would prefer to have only unions, only works councils, unions and works councils, or none of these forms at their workplace. By asking several questions about desired workplace representation appropriate to the country setting, the surveys give a much richer picture of preferences for collective representation than simple "union - yes or no" questions. But this design also complicates measurement of desire for unionism or other forms of representation and comparisons across the two countries, since the institutional options differ. We combined the responses to the different questions to obtain an ordering of the desire for unionism that had values from 0 to 6 for the US and UK, where 0 represents the least desire for unions and 6 represents the greatest desire for unions. 
In both surveys we coded each of the three questions from 0 to 2 and formed summated ratings for the desire for collective representation. For the US, on the voting question, we scored a 2 if workers said they would vote for a union in an NLRB election, scored 1 if they said they would switch their vote depending on employer attitudes and 0 if they would vote no. ${ }^{21}$ Fifty-nine per cent of all employees in WRPS scored zero, $4 \%$ scored 1 and $37 \%$ scored 2 on this item. On the desired organization question, we gave a 2 if they chose a union/employee organization that collectively bargained; a 1 if they chose a joint committee; and a 0 otherwise. Twenty-six per cent favored collective bargaining and $58 \%$ chose a joint committee. On the attributes of a workplace committee question, we gave a 2 if they preferred workers to vote for committee members, that the organization be employee run, and if they wanted an outside arbitrator to resolve disagreements; a 1 if they chose 2 of these 3, and 0 otherwise. Six per cent favored all three options, $39 \%$ favored two of the options. For the UK, we gave a score of 2 to workers who thought unions made the workplace a lot better, a score of 1 if they thought unions make the workplace a little better, and 0 otherwise. On the likelihood of joining a union question, for non-union members we gave a score of 2 if they said very likely, a score of 1 if they said quite likely, and 0 otherwise; for union members we gave a score of 2 if they said membership was 'good value for money', a score of 1 if they said 'reasonable value' and 0 otherwise. Twenty-nine per cent said it represented 'good value for money'. On the question regarding unions and works councils, we gave a score of 2 if they said they wanted a union (either on its own or with a works council), a score of 1 if they wanted a works council but no union, and zero otherwise. Sixteen percent of non-union workers in non-union workplaces said they would be very likely to join a union at their workplace if one was formed, and an additional $29 \%$ said they were quite likely to join. But just $19 \%$ of non union workers said the workplace would be a lot or a little better with a union.

Panel A of Table 4 shows the distribution of responses of non-union workers in the US and the UK on this 0-6 scale. In the US, the mean value is 2.15 , with one-fifth of non-members scoring

\footnotetext{
${ }^{21}$ That is, when a worker said they would vote union only in the absence of employer opposition to a union, or said they would change a 'no' vote to a 'yes' if they thought management would not oppose the union, we coded this item ' 1 '.
} 
$4+$ and $8 \%$ scoring zero. In the UK, the mean score is 1.84 , with one-sixth of non-union workers scoring $4+$ and $26 \%$ scoring zero - over three times the percent for the US.

Panel B displays the scores for union members in the US and the UK. The scores for the UK are more polarized than those for the US: UK members are more likely to score the maximum 6 (15\% against $6 \%$ in the US) and more likely to score below 3 (9\% compared with $16 \%$ in the US). But the mean scores are similar for members in the two countries. Very few members score zero. Panel $\mathrm{C}$ gives estimates of the proportion of workers in unionized settings in the US and UK who prefer non-union status. For the UK this is the proportion of workers who report a union at their workplace that they could join but have not joined - free riders-35\%. For the US the estimate is the proportion of union members who said they would vote to remove the union in an NLRB decertification election. As a percentage of union members this is $9 \%$; as a percentage of all non-managerial employees in a unionised environment it is $18 \%$.

In short, proportionately more non-union workers in the US than in the UK are favorably inclined to unions; whereas UK workers are more inclined than US workers to favor works councils. And the proportion of workers in unionized workplaces that free ride in the UK exceeds the proportion of unionized workers who would get rid of their local union in the US if they could.

\section{Determinants of Desire for Unions in Non union Workplaces}

We seek to explain these patterns in terms of worker needs and the options that management, unions, and the legal system offer workers to meet these needs. We consider first the effect of needs, management attitudes toward unionism, and HR practices on the preferences toward unionism of workers in non-union workplaces. For simplicity, in this analysis we measure HR practices by the number of policies at the workplace: this variable ranges from 0 to $6{ }^{22}$

Table 5 gives the regression coefficients and t-statistics on the estimated effects of specified factors from a linear probability model of the desire for union representation among workers in nonunion workplaces in the WRPS and BWRPS data sets. We give estimates for models for the UK

\footnotetext{
${ }^{22}$ Estimating the model with dummy variables for each policy, we found that they affected the desire for unionism with similar coefficients, which contrasts with the table 2 finding that open door policies reduced needs the most.
} 
and US separately and then for a pooled sample for the two countries. The models for the US and UK give similar results. The desire for unions rises with needs, with a larger estimated coefficient for the US than for the UK. The U-shaped effect of perceived management attitudes to unions is evident in both countries. The substitution effect of the HRM count is only significant in the US, though the coefficient is also negatively signed in the UK. In the UK members in non-union workplaces express a strong desire for unionisation; the absence of union members in non-union workplaces in the US means this term falls out of the US equation. The pooled regression shows desire for unions in the non-union sector is stronger in the US than the UK.

Why is the relation between preference for a union and management opposition U-shaped in both countries? It is reasonable that when an employer favors unions, workers would also be more favorable to them. The surprise is that workers also favor unions when management opposition is severe. The most plausible interpretation of this result is that strong management opposition to unionism reflects a tough policy towards workers. If this interpretation were correct, we would expect to find that workers with many needs and facing management opposition ought to be driving the relation between strong opposition and desire for unionism. To test this, we divided the sample between workers in the upper third of the distribution of needs and the rest of the workers. In the UK, management opposition increased the desire for collective representation only among nonmembers in the top third of the needs distribution but in the USA, management opposition increased the desire for collective representation regardless of needs (see Appendix C).

We also estimated a model for non-members in non-union workplaces on the WERS data file (Appendix D). The WERS asked whether workers wanted unions to represent them for pay, grievance procedures, and making a complaint. We measured the desire for union representation on a 0 to 3 scale depending on how many times a worker said they wanted representation. ${ }^{23}$ As in table 5, we found that the needs variable had a great impact on workers wanting union representation, even in a fixed effects analysis that controlled for the workplace. The WERS

\footnotetext{
${ }^{23}$ WERS asks workers to identify who best represented them in relation to getting pay increases, making a complaint about working, and if management wanted to discipline the worker, with 'trade union' being one of four options.
} 
regressions show a positive relation between management communication policies and the desire for unions. Confirming the result in table 5, management support or opposition to unions gives the same U shaped relation that we found in the WRPS and BWRPS.

The regressions in table 5 explain the differing attitudes of workers within the US and UK toward unions but the pooled regression shows that there is a substantial cross-country difference that remains: workers in non-union workplaces are more favourably inclined toward unions in the US than in the UK. The estimated coefficient on the US dummy in the regression is a highly significant 0.339 . The mean value of the union desire variable for non-union workers in the US is 2.15 while the mean value for the union desire variable for non-union workers in the UK is 1.84 , which gives a slightly lower difference of 0.31 . The implication is that while the regressions explain the differences in desire for unionism within country, they do not explain the cross-country differential at all; rather they widen the estimated US-UK difference.

How can we explain the cross-country difference in the desire for unionism? Our analysis directs attention at the differing institutions on offer in the two countries and the resultant difference in union density. US workers lack the intermediate institutions for voice that exist in the UK and face large difficulties in organizing so that many more non-union workers favor unions in the US than in the UK. To test this explanation, we conducted a simulation analysis in which we estimated what the desire for unionism among non-union workers in the two countries would be if each country had the unionization rate of the other country. The basic idea is that if more US (fewer UK) workers had union status, the difference in desire for unionism among non-union workers between the countries should be less. We did this in a three step analysis. First, we estimated equations that predict worker desire for unionism on our 0 to 6 scale, using the regression structure in table 5 , but applying the model to all workers. Second we ranked workers by their predicted desire for unionism. Third, we estimated what the mean desire on non-union workers would be if more workers were organized in the US or if fewer workers were unionized in the UK. The key assumption in this calculation is that additional unionization would come from non-union workers 
with the highest desires for unionism or conversely, that reduced unionization would come from unionized workers with the least desire for unions.

Table 6 gives the results of this analysis. We estimate that if the US had the proportion of workers unionized in the UK sample (34\%), the desire for unionism among non-union US workers would fall from 2.15 to 1.95 - a 0.20 drop that accounts for $65 \%$ of the 0.31 point gap between US and UK non-union workers. Similarly, we estimate that if the UK had the proportion of workers unionized in the US sample (14\%), the desire for unionism among UK workers would rise to 2.23 a 0.39 increase that actually exceeds the US-UK gap. One possible reason for the larger change in the difference in the desire for unionism is that the unionized workers in the UK who by our analysis would lose their union status have developed greater desire for unionism as a result of their experience with it (Bryson and Gomez, 2003). ${ }^{24}$

\section{Determinants of Attitudes Toward Unions in Union Workplaces}

What about the workers in organized workplaces choosing to free ride or otherwise reject unions? Table 7 examines the attitudes of workers in union workplaces toward unions. Column 1 gives the estimated coefficients and t-statistics for the factors that lead a worker in the UK to freeride in a workplace where there is a union the worker could join. Free-riding is lower when needs are higher, when workers think management favors the union and when they perceive unions as more effective. HR policies do not affect the likelihood of free riding. Column 2 examines the factors that lead a worker in a unionized workplace in the USA to favor decertifying the union. This is not the same as being a 'free-rider' but it is the best measure in the US of the desire of workers in an organized work place to reject unions. The estimated coefficients on the variables have the same sign as in column 1 but are weaker in magnitude and significance. Assessment of union effectiveness is the statistically strongest variable.

The remaining columns examine the determinants of the desire for unionism using our 0-6 measure of the desire. The coefficients on the variables have opposite signs to those in columns 1

\footnotetext{
${ }^{24}$ We also estimated the model using the equations for non-union workers in table 5 and obtained comparable results.
} 
and 2 , since they measure favourableness toward unions. The coefficients on need and union effectiveness are larger and more significant in the UK than in the US. This reflects the fact that the UK sample includes the free riders, so the UK regression differentiates the desire for unions among members, who have greater needs and who see the union as more effective, from the desire of workers who have chosen to be non-members. In the pooled regression, all of the variables except for the count of HR policies are statistically significant and parallel the results for workers in the non-union sector in table 5. The dummy coefficient for the US is positive significant, as is the dummy coefficient for union members in the UK. The group with the least desire for unionisation are non-members in the UK, who in fact are able to express their lack of desire through free-riding.

\section{Conclusions}

This paper has compared the preferences of workers in the US and UK for unions and other forms of employee voice in a period of declining union density. It shows that US workers have a high and seemingly increasing unfilled demand for unionism while a growing proportion of UK workers have chosen to free ride at unionized work places. The key factor determining worker desire for unions or other forms of collective voice in both countries is the number of needs or problems that workers report. Using the responses of multiple workers at the same workplace, we show that needs have a significant workplace component, but that even within the same workplace, workers who report greater needs/problems are more likely to favor unions. The different choices on offer in the two countries appear to affect the different responses of UK and US workers to fairly similar workplace needs/problems. The dichotomous choice between collective bargaining and no representation in the US produces a smaller rate of unionization in the US that manifests itself in greater unfilled demand for unions among non-union workers than in the UK; whereas the wider choice of voice institutions in the UK attracts many to take the free rider option. 


\section{References}

Airey, Colin, Jon Hales, Rosemary Hamilton, Christos Korvovessis, Anthony McKernan and Susan Purdon (1999). The Workplace Employee Relations Survey (WERS) 1997-8: Technical Report. National Centre for Social Research.

Blanchflower, D. (2006) ‘A Cross-Country Study of Union Membership', IZA Discussion Paper \#2016

Blanchflower, D. and Bryson, A. (2004) 'Union Relative Wage Effects in the United States and the United Kingdom', Proceedings of the $56^{\text {th }}$ Annual Meeting of the Industrial Relations Research Association, 133-140

Blanchflower, D. and Bryson, A. (2003) 'Changes over time in union relative wage effects in the UK and the US Revisited', chapter 7 in International Handbook of Trade Unions, John T. Addison and Claus Schnabel (eds.), Edward Elgar, Cheltenham England and Northampton Mass., USA

Boxall, Peter, Richard Freeman and Peter Haynes (eds). What Workers Say: Employee Voice in the Anglo-American World. (forthcoming, Cornell University Press, 2006).

Bryson, Alex (2006) 'Union Free-riding in the UK and New Zealand', CEP Discussion Paper Number 713, LSE

Bryson, Alex (2005) 'Working With Dinosaurs? Union Effectiveness in Britain', in G.Gall (ed.) Union Recognition: Organising and Bargaining Outcomes, pp. 25-43, Routledge, London

Bryson, Alex (2004) 'Managerial responsiveness to union and non-union worker voice in Britain', Industrial Relations: A Journal of Economy and Society, Vol. 43, No. 1, 213-241

Bryson, Alex and Richard Freeman. (2006) 'Can Unions Deliver What Workers Want in Great Britain?', CEP Discussion Paper forthcoming

Bryson, Alex and Rafael Gomez (2005) 'Why Have Workers Stopped Joining Unions? Accounting for the Rise of Never-Membership in Britain', British Journal of Industrial Relations, 43, 1: 67-92

Bryson, Alex and Rafael Gomez. (2003) 'Buying Into Union Membership', in Gospel, H. and Wood, S. (eds.), Representing Workers: Union Recognition and membership in Britain, Routledge, London

Bryson, Alex and Rafael Gomez. (2002) 'Marching on together? Recent trends in union membership' in Park, A., Curtice, J., Thomson, K., Jarvis, L. and Bromley, C. (eds) British Social Attitudes: the 19th Report, London: Sage.

Bryson, Alex, Rafael Gomez and Paul Willman. (2004) 'The End of the Affair? The Decline in Employers' Propensity to Unionize', Chapter 8 in J. Kelly and P. Willman (eds.), Union Organization and Activity, Routledge, London, pp.129-149

Bureau of Labor Statistics (2006) 'Union Members in 2005', news release January 20th

Cully, M., Woodland, S., O'Reilly, A. and Dix, G. (1999) Britain at Work: as depicted by the 1998 Workplace Employee Relations Survey, Routledge: London 
Diamond Wayne and Richard Freeman (2001) What Workers Want from Workplace Organisations, Trade Unions Congress Publications, London

Farber, Henry S. (1989) 'Trends in Worker Demand for Union Representation', AER, Vol. 79, Issue 2, Papers and Proceedings of the Hundred and First Meeting, 166-171

Farber, Henry S. and Alan B. Krueger (1992) Union Membership in the United States: The Decline Continues, NBER Working Paper No. 4216

Farber, H. S. and Western, B. (2000) "Round Up the Usual Suspects: The Decline of Unions in the Private Sector, 1973-1998”, Princeton University Working Paper No. 437, Industrial Relations Section

Farber, H. S. and Western, B. (2001) "Ronald Regan and the Politics of Declining Union Organization”, Princeton University Working Paper No. 460, Industrial Relations Section

Flanagan, Robert J., "Has Management Strangled U.S. Unions?” Journal of Labor Research 26:1 (Winter) 2005.

Freeman, Richard (2006) 'What Do Unions Do?: the 2004 M-Brane Stringtwister edition' in James T. Bennett and Bruce E. Kaufman, eds. What Do Unions Do? The Evidence Twenty Years Later,

Freeman, Richard and James Medoff (1984) What Do Unions Do, Basic books 1984

Freeman, Richard and Joel Rogers (1999) What Workers Want, Cornell

Grainger, H. (2006) Trade Union Membership 2005, London: Department of Trade and Industry.

Lerner, Stephen, Three Steps To Reorganizing And Rebuilding The Labor Movement December 2002, http://www.labornotes.org/archives/2002/12/e.html

LeRoy, M. (2006) 'The Power to Create or Obstruct Employee Voice: Does U.S. Public Policy Skew Employer Preference for “No Voice” Workplaces?', Socio-economic Review, 4, 311-319

Lipset, S.M. and N. Meltz, (2004). The Paradox of American Unionism. Cornell University Press.

Logan, John (2002) 'Consultants, lawyers and the 'union free' movement in the USA since the 1970s', Industrial Relations Journal, 33:3: 197-214

McLennan, Kenneth. (2005) “A Management Perspective on What Do Unions Do?” In James T. Bennett and Bruce E. Kaufman, eds. What Do Unions Do? The Evidence Twenty Years Later.

Millward, Neil, Alex Bryson, and John Forth. (2000) All Change at Work?, Routledge, London.

Terry, Mike (2004) in Verma, Anil and Tom Kochan (eds.) Unions in the $21^{\text {st }}$ Century: An International Perspective, Palgrave

Willman, Paul and Alex Bryson (2005) 'Things Can Only Get Better: A Picture of Union Finances at the End of the $20^{\text {th }}$ Century', SASE Conference Paper 
Table 1: Tests of the impact of workplace on worker needs

\begin{tabular}{|l|l|l|l|}
\hline & $\begin{array}{l}\text { Workplace } \\
\text { dummies + } \\
\text { constant }\end{array}$ & $\begin{array}{l}\text { Demographic } \\
\text { and job } \\
\text { characteristics }+ \\
\text { constant }\end{array}$ & $\begin{array}{l}\text { Demographic and } \\
\text { job } \\
\text { characteristics + } \\
\text { workplace } \\
\text { dummies + } \\
\text { constant }\end{array}$ \\
\hline $\begin{array}{l}r \text {-sq, weighted } \\
\text { model }\end{array}$ & .203 & .107 & .256 \\
\hline $\begin{array}{l}\text { r-sq unweighted } \\
\text { model }\end{array}$ & .194 & .089 & .241 \\
\hline $\begin{array}{l}\text { F-test for } \\
\text { workplace } \\
\text { dummies in } \\
\text { unweighted model }\end{array}$ & $\begin{array}{l}\mathrm{f}(1758,23692)=3.24 \\
\mathrm{P}>\mathrm{f}=0.0000\end{array}$ & NA & $\begin{array}{l}\mathrm{f}(1758,23647)=2.6 \\
8 \mathrm{p}>\mathrm{f}=0.0000\end{array}$ \\
\hline
\end{tabular}

Notes:

$\mathrm{N}=25,451,1,759$ workplaces.

Regressors in columns 2 and 3: female, union member, age (6 dummies), ethnicity, health problem, married or living as married, academic qualifications (6 dummies), vocational qualifications, occupation ( 9 dummies), tenure (4 dummies), hours ( 5 dummies), gender segregation on the job (5 dummies), banded gross weekly wages (11 dummies), permanent contract. 
Table 2: Regression estimates of determinants of needs (measured as scalar variable from 0 to 1) in the USA and UK, by membership status

\begin{tabular}{|l|l|l|l|l|l|l|}
\hline & \multicolumn{3}{|l}{ All workers } & \multicolumn{4}{l|}{ Non-members } & \multicolumn{2}{l|}{ Members } \\
\hline & $\boldsymbol{U S A}$ & $\boldsymbol{U} \boldsymbol{U}$ & $\boldsymbol{U S A}$ & $\boldsymbol{U} \boldsymbol{U}$ & $\boldsymbol{U S A}$ & UK \\
\hline Member & 0.025 & 0.061 & - & - & - & - \\
\hline & $(2.33)^{*}$ & $(5.49)^{* *}$ & - & - & - & - \\
\hline $\begin{array}{l}\text { Management } \\
\text { attitudes to } \\
\text { union (ref.: } \\
\text { neutral) }\end{array}$ & & & & & & \\
\hline Opposed & 0.045 & 0.094 & 0.043 & 0.088 & 0.050 & 0.122 \\
\hline & $(6.63)^{* *}$ & $(7.66)^{* *}$ & $(6.10)^{* *}$ & $(6.60)^{* *}$ & $(2.00)^{*}$ & $(4.37)^{* *}$ \\
\hline In favour & -0.014 & -0.040 & -0.009 & 0.018 & -0.012 & -0.079 \\
\hline & $(0.92)$ & $(3.49)^{* *}$ & $(0.50)$ & $(1.13)$ & $(0.31)$ & $(4.52)^{* *}$ \\
\hline Substitutes: & & & & & & \\
\hline Open door & -0.103 & -0.059 & -0.102 & -0.060 & -0.119 & -0.048 \\
\hline & $(12.34)^{* *}$ & $(6.45)^{* *}$ & $(11.35)^{* *}$ & $(5.47)^{* *}$ & $(4.67)^{* *}$ & $(2.76)^{* *}$ \\
\hline Committee & -0.038 & -0.033 & -0.041 & -0.019 & -0.023 & -0.058 \\
\hline & $(5.81)^{* *}$ & $(3.51)^{* *}$ & $(5.89)^{* *}$ & $(1.77)$ & $(1.09)$ & $(3.16)^{* *}$ \\
\hline $\begin{array}{l}\text { Profit-related } \\
\text { pay }\end{array}$ & -0.010 & -0.017 & -0.017 & -0.021 & 0.029 & 0.002 \\
\hline & $(1.33)$ & $(1.56)$ & $(2.23)^{*}$ & $(1.67)$ & $(1.03)$ & $(0.09)$ \\
\hline ESOP & -0.018 & -0.008 & -0.016 & -0.019 & -0.033 & -0.024 \\
\hline & $(2.22)^{*}$ & $(0.52)$ & $(1.82)$ & $(0.94)$ & $(1.29)$ & $(0.82)$ \\
\hline $\begin{array}{l}\text { Performance } \\
\text { pay }\end{array}$ & -0.016 & -0.018 & -0.013 & -0.023 & -0.047 & -0.010 \\
\hline & $(2.18)^{*}$ & $(1.64)$ & $(1.64)$ & $(1.86)$ & $(1.74)$ & $(0.45)$ \\
\hline $\begin{array}{l}\text { HR } \\
\text { department }\end{array}$ & 0.006 & -0.000 & 0.003 & -0.004 & 0.018 & -0.001 \\
\hline & $(0.81)$ & $(0.01)$ & $(0.37)$ & $(0.29)$ & $(0.67)$ & $(0.06)$ \\
\hline $\begin{array}{l}\text { Grievance } \\
\text { Procedure }\end{array}$ & -0.011 & 0.021 & -0.016 & 0.019 & 0.024 & 0.020 \\
\hline & $(1.50)$ & $(2.17)^{*}$ & $(2.00)^{*}$ & $(1.52)$ & $(0.89)$ & $(1.12)$ \\
\hline Constant & 0.220 & 0.218 & 0.227 & 0.204 & 0.121 & 0.260 \\
\hline & $(9.47)^{* *}$ & $(6.26)^{* *}$ & $(9.08)^{* *}$ & $(4.92)^{* *}$ & $(1.41)$ & $(3.89)^{* *}$ \\
\hline Observations & 2049 & 1355 & 1767 & 889 & 282 & 466 \\
\hline R-squared & 0.20 & 0.24 & 0.20 & 0.18 & 0.31 & 0.36 \\
\hline
\end{tabular}

Notes: all models contain the following controls - male, age (5 dummies), ethnicity, marital status, any children, education (4 dummies), hours worked (3 dummies), tenure with employer (4 dummies), occupation (8 dummies), if supervisor, banded earnings (12 dummies), organization with 1000+ employees, workplace size (5 dummies), industry (9 dummies) 
Table 3: Worker Preferences for Dealing With Workplace Problems

\begin{tabular}{|c|c|c|}
\hline \multicolumn{3}{|c|}{ Panel A: Percent who prefer to solve problems: } \\
\hline & with help of fellow employees & by self \\
\hline \multicolumn{3}{|l|}{ Terms and conditions } \\
\hline US: Benefits & 66 & 33 \\
\hline Health and safety & 53 & 36 \\
\hline$U K$ : Negotiating salary & 57 & 43 \\
\hline Negotiating conditions & 60 & 40 \\
\hline \multicolumn{3}{|l|}{ Career progression \& development } \\
\hline US: Training & 44 & 54 \\
\hline UK: Training/skill development & 47 & 53 \\
\hline Promotion issues & 35 & 65 \\
\hline \multicolumn{3}{|l|}{ Protection } \\
\hline US: Unfair treatment & 39 & 59 \\
\hline Harassment & 34 & 65 \\
\hline UK: Sex/racial discrimination & 67 & 33 \\
\hline Bullying & 62 & 38 \\
\hline \multicolumn{3}{|l|}{ Panel B: \% who: } \\
\hline \multirow{4}{*}{\multicolumn{2}{|c|}{$\begin{array}{l}\text { US: } \\
\text { Want organization with no power but management cooperation } \\
\text { Want more power but management opposes } \\
\text { Do not prefer either/don't know }\end{array}$}} & \\
\hline & & 63 \\
\hline & & 22 \\
\hline & & 15 \\
\hline \multicolumn{2}{|l|}{ US: } & \\
\hline \multirow{3}{*}{\multicolumn{2}{|c|}{$\begin{array}{l}\text { Believes organization effective only if management } \\
\text { Can be effective without management cooperation } \\
\text { Don't know }\end{array}$}} & 73 \\
\hline & & 17 \\
\hline & & 9 \\
\hline \multicolumn{2}{|l|}{$U K$} & \\
\hline \multirow{3}{*}{\multicolumn{2}{|c|}{$\begin{array}{l}\text { Want organization to work with management to improve the } \\
\text { workplace and working conditions } \\
\text { Want organization to defend workers against unfair treatment by } \\
\text { management } \\
\text { Don't know }\end{array}$}} & 74 \\
\hline & & \\
\hline & & 3 \\
\hline
\end{tabular}

Sources: US - WRPS; UK - BWRPS 
Table 4: Percent of Non-members Favouring Different Voice Options in the US and the UK

\begin{tabular}{|l|l|l|}
\hline \multicolumn{2}{|l|}{} & USA \\
\hline $\begin{array}{l}\text { Panel A: Distribution of Desire of Non-union Workers } \\
\text { for Unions, on 0 to 6 Scale }\end{array}$ & \multicolumn{2}{l|}{} \\
\hline 6 (Highest pro-union answer on all questions) & 2 & 5 \\
\hline 5 & 8 & 5 \\
\hline 4 & 11 & 8 \\
\hline 3 & 13 & 12 \\
\hline 2 & 21 & 18 \\
\hline 1 & 27 & 26 \\
\hline 0 & 8 & 26 \\
\hline Mean & 2.15 & 1.84 \\
\hline $\begin{array}{l}\text { Panel B: Distribution of Desire of Union Members for } \\
\text { Unions, on 0 to 6 Scale }\end{array}$ & & \\
\hline 6 (Highest pro-union answer on all questions) & 6 & 15 \\
\hline 5 & 29 & 24 \\
\hline 4 & 37 & 24 \\
\hline 3 & 20 & 20 \\
\hline 2 & 7 & 10 \\
\hline 1 & 1 & 4 \\
\hline 0 & $<1$ & 2 \\
\hline Mean & 4.00 & 3.94 \\
\hline $\begin{array}{l}\text { Panel C: Preferences of Workers in Unionized Workplaces } \\
\text { For Free Riding Status }\end{array}$ & & \\
\hline $\begin{array}{l}\text { \% workers in organized workplaces who do not join union even } \\
\text { when one is there for workers like them }\end{array}$ & - & 35 \\
\hline$\%$ of union members who would vote against union & 9 & - \\
\hline $\begin{array}{l}\text { \% of all non-managerial employees in union workplaces who } \\
\text { would vote against union }\end{array}$ & 18 & - \\
\hline Notes: coun perentages. Sources: WRPS and BWRS. & \\
\hline
\end{tabular}

Notes: column percentages. Sources: WRPS and BWRPS. See text for construction of variables. Unweighted Ns for non-union workers: USA=1,767; UK=889. Panel B base for USA members in unionized workplaces, unweighted $\mathrm{N}=282$. Panel $\mathrm{B}$ base for $\mathrm{UK}$ is all union members, unweighted $\mathrm{N}=466$. Last row is \% of all workers in a union workplace $(\mathrm{n}=428)$ who were non-managerial nonmembers who would vote against the union. 
Table 5: Union desire among workers in non-union workplaces

\begin{tabular}{|l|l|l|l|}
\hline & $(\mathbf{1})$ UK & $(\mathbf{2}) \mathbf{U S}$ & $(\mathbf{3})$ Pooled \\
\hline Needs & 3.772 & 2.445 & 3.041 \\
\hline $\begin{array}{l}\text { Management } \\
\text { attitudes (ref.: } \\
\text { neutral) }\end{array}$ & $(9.42)^{* *}$ & $(9.31)^{* *}$ & $(14.01)^{* *}$ \\
\hline Opposed & & & \\
\hline & 0.628 & 0.388 & 0.458 \\
\hline In favour & $(4.00)^{* *}$ & $(4.87)^{* *}$ & $(6.46)^{* *}$ \\
\hline & 0.779 & 0.748 & 0.757 \\
\hline $\begin{array}{l}\text { Count of human } \\
\text { resource policies }\end{array}$ & $(2.97)^{* *}$ & $(3.10)^{* *}$ & $(4.38)^{* *}$ \\
\hline & -0.061 & -0.097 & -0.070 \\
\hline Member & $(1.06)$ & $(3.07)^{* *}$ & $(2.56)^{*}$ \\
\hline & 1.164 & 0.000 & 1.325 \\
\hline USA dummy & $(4.38)^{* *}$ & $()$. & $(5.54)^{* *}$ \\
\hline & & & 0.339 \\
\hline Constant & 0.651 & & $(3.97)^{* *}$ \\
\hline & $(1.32)$ & 1.642 & 1.061 \\
\hline Observations & 692 & $(5.93)^{* *}$ & $(4.36)^{* *}$ \\
\hline R-squared & 0.33 & 1604 & 2296 \\
\hline Note: Linear & 0.17 & 0.21 \\
\hline
\end{tabular}

Note : Linear regression models for union desire. T-statistics in parentheses. See text for description of the $(0,6)$ desire for unions scales for the US and the UK. Needs measured as described in text. Human resource policies count gives a score of ' 1 ' given every time the employee says one of the policies is present at the workplace. Performance-related pay is not added to the count but is contained in the controls. The union effectiveness variable for the UK is an additive scale running from zero to eight with a point scored every time the worker rates the union A or B on eight dimensions, namely: winning fair pay increases, understanding and knowledge of the employers' business, being open and accountable to members, sharing information they have about the employer, promoting equal opportunities, working with management to increase quality or productivity, making work interesting and enjoyable, protecting workers against unfair treatment. In the USA, the union effectiveness scale runs from 1 to 4 where 1 is 'not effective at all' and 4 is 'very effective'. See notes to Table 2 for controls. 
Table 6: Estimated Impact of Institutions on Offer on Desire to Unionize and Free Riding

\begin{tabular}{|l|c|c|}
\hline & USA & UK \\
\hline $\begin{array}{l}\text { Actual mean desire for union, non- } \\
\text { members }\end{array}$ & 2.15 & 1.84 \\
\hline USA-UK gap & \multicolumn{2}{|c|}{0.31} \\
\hline $\begin{array}{l}\text { Predicted US mean desire with UK union } \\
\text { density }\end{array}$ & 1.95 & - \\
\hline $\begin{array}{l}\text { Predicted UK mean desire with US union } \\
\text { density }\end{array}$ & - & 2.23 \\
\hline Difference in gap explained by model & 0.20 & 0.39 \\
\hline
\end{tabular}

Notes

(1) In our sample $34 \%$ of UK workers are members compared to $14 \%$ in the US. Above simulation uses predicted desire for unionisation to 'simulate' density in other country.

(2) Predictions use all worker separate models for the USA and UK.

(3) The predicted US mean desire with UK density is a prediction for 'simulated non-members' in the US having

eliminated all workers who are in the top 34\% of the predicted distribution. The reasoning is that these top 34\% would have been union members in the UK.

(4) The predicted UK mean desire with US union density for 'simulated non-members' in the UK having eliminated all workers who are in the top $14 \%$ of the predicted desire distribution in the UK. The reasoning is that only these top 14\% of workers would have been union members in USA. 
TABLE 7: Union Attitudes Of Workers in the Union Sector

\begin{tabular}{|c|c|c|c|c|c|}
\hline & UK & US & UK & $\mathbf{U S}$ & Pooled \\
\hline & $\begin{array}{l}\text { Probability } \\
\text { of } \\
\text { Workers } \\
\text { Free- } \\
\text { riding }\end{array}$ & $\begin{array}{l}\text { Probability } \\
\text { members } \\
\text { would vote } \\
\text { to } \\
\text { decertify } \\
\text { union }\end{array}$ & \multicolumn{3}{|c|}{ Union desire (0-6) } \\
\hline \multirow[t]{2}{*}{ Needs } & -0.533 & -0.044 & 1.963 & 0.134 & 0.988 \\
\hline & $(4.87)^{* *}$ & $(0.03)$ & $(5.19)^{* *}$ & $(0.29)$ & $(3.50)^{* *}$ \\
\hline \multicolumn{6}{|c|}{$\begin{array}{l}\text { Management } \\
\text { Attitudes } \\
\text { (ref: neutral) }\end{array}$} \\
\hline \multirow[t]{2}{*}{ Opposed } & 0.008 & -0.071 & 0.349 & 0.452 & 0.403 \\
\hline & $(0.13)$ & $(1.43)$ & $(1.65)$ & $(2.54)^{*}$ & $(3.10)^{* *}$ \\
\hline \multirow[t]{2}{*}{ In favor } & -0.104 & -0.051 & 0.455 & 0.247 & 0.315 \\
\hline & $(2.77)^{* *}$ & $(0.68)$ & $(3.51)^{* *}$ & $(0.93)$ & $(2.97)^{* *}$ \\
\hline \multirow{2}{*}{$\begin{array}{l}\text { Count of } \\
\text { human } \\
\text { resource } \\
\text { policies }\end{array}$} & -0.014 & -0.015 & 0.033 & 0.036 & 0.028 \\
\hline & $(0.97)$ & $(0.89)$ & $(0.65)$ & $(0.60)$ & $(0.77)$ \\
\hline \multirow{2}{*}{$\begin{array}{l}\text { Count for } \\
\text { union } \\
\text { effectiveness }\end{array}$} & -0.040 & -0.081 & 0.243 & 0.110 & 0.184 \\
\hline & $(5.99) * *$ & $(2.98)^{* *}$ & $(10.42)^{* *}$ & $(1.13)$ & $(9.09)^{* *}$ \\
\hline \multirow[t]{2}{*}{$\begin{array}{l}\text { UK union } \\
\text { member }\end{array}$} & & & & & 1.365 \\
\hline & & & & & $(11.45)^{* *}$ \\
\hline \multirow[t]{2}{*}{ USA dummy } & & - & & & 1.530 \\
\hline & & - & & & $(9.92)^{* *}$ \\
\hline \multirow[t]{2}{*}{ Constant } & 0.861 & 0.507 & 0.250 & 3.572 & 0.325 \\
\hline & $(5.86)^{* *}$ & $(2.67)^{* *}$ & $(0.49)$ & $(5.28) * *$ & $(0.91)$ \\
\hline Observations & 663 & 277 & 663 & 277 & 940 \\
\hline R-squared & 0.30 & 0.25 & 0.33 & 0.24 & 0.38 \\
\hline
\end{tabular}

Note : See notes to Tables 2 and 5 for controls. Dependent variables are as follows. Column 1: union non-membership. Column 2: responding 'get rid of the union' in response to the question: "If a new election were held TODAY to decide whether to keep the union at your (company/organization), would you vote to keep the union or get rid of it?" Columns 3-5: desire for union on the $(0,6)$ scale described in the text. Populations are as follows. Columns 1 and 3: all UK workers in unionised workplaces. Columns 2 and 4: US members in unionized workplaces. Column3: all US workers in unionised workplaces. Column 5: all UK workers in union workplaces and US members in union workplaces. 
Figure 1: Percentage of Non-union Worker Likely to Vote For/Against Unions in NLRB Election, Peter Hart Surveys, 1984-2005

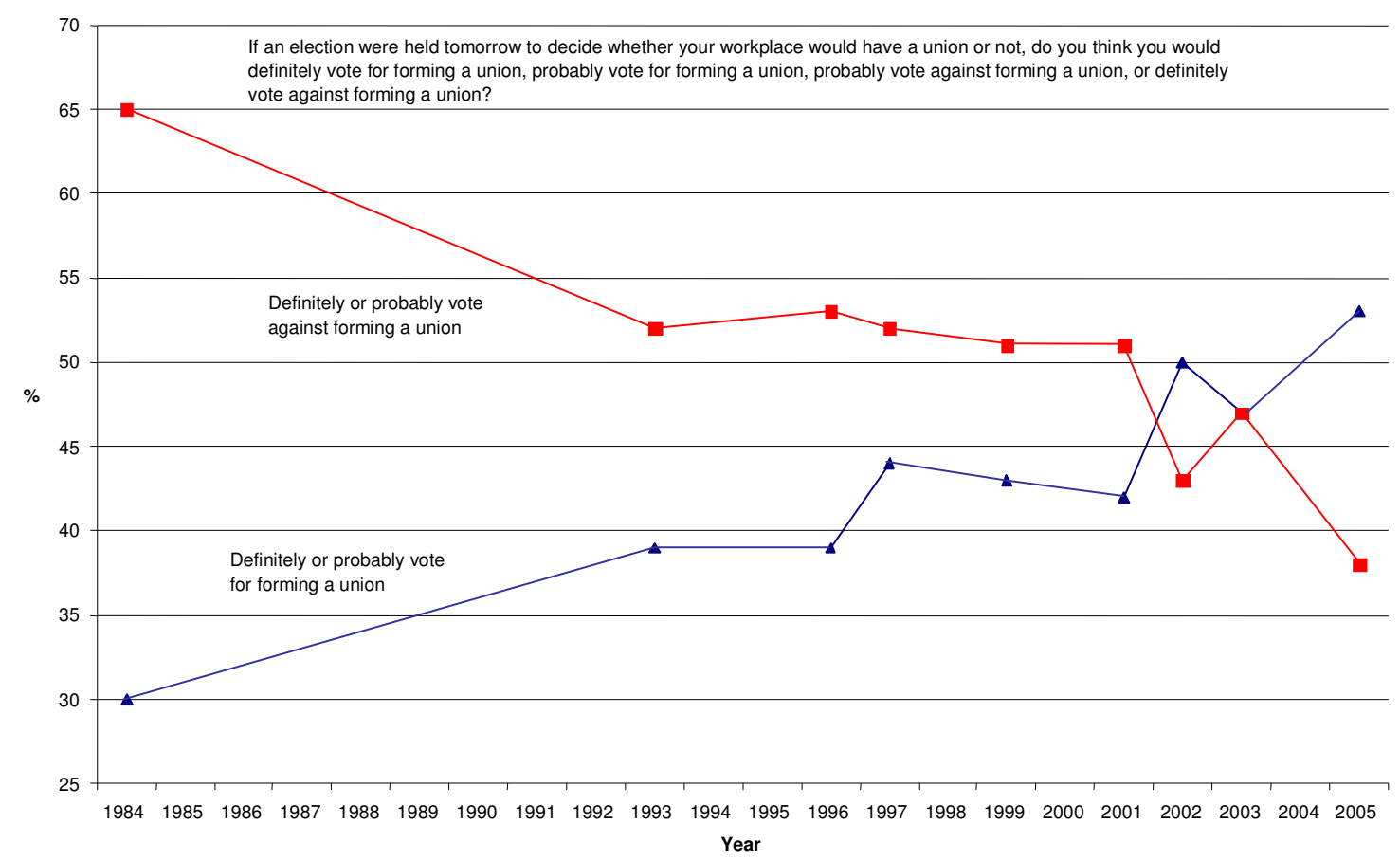

Source: Hart Research Associates, various polls, except 1984, when data are from Harris, for question: "If an election were held tomorrow to decide whether your workplace would be unionized or not, do you think you would definitely vote for a union, probably vote for a union, probably vote against a union, or definitely vote against a union?"

Figure 2: Percentage of Free-riders in Britain and the USA, 1980-2005

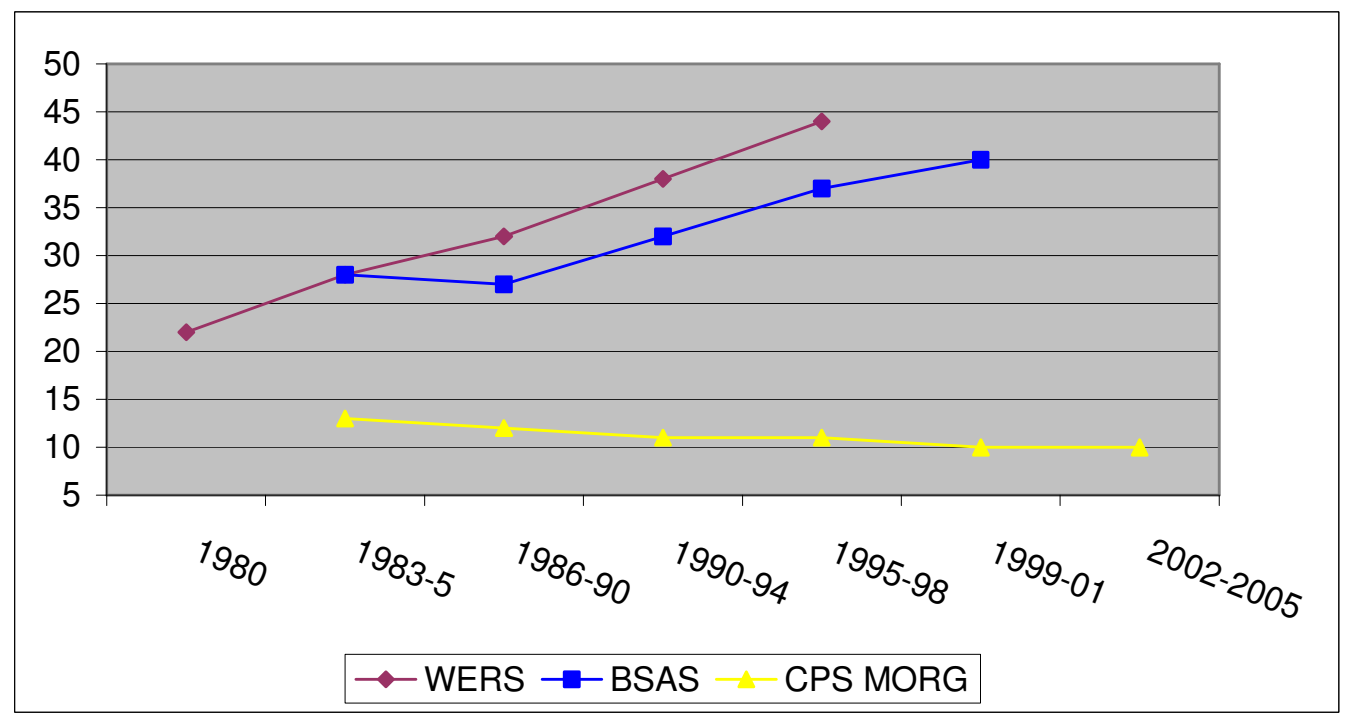

Notes: For Britain, figures are \% non-members in workplaces recognizing unions for pay bargaining. WERS data adapted from Millward et al. (2000: 142). Establishments with 25+ employees where one or more unions recognized for pay bargaining and where number of members reported. Figures based on surveys in 1980 (full-time employees only), 1984, 1990 and 1998. BSAS adapted from Bryson and Gomez (2005, Table 8). Employees working 10+ hours per week. Figures based on surveys in all years between 1983 and 2001 except 1988 and 1992. For the USA, figures are \% of covered workers who are non-members. Figures based on annual MORG Outgoing Rotation Files, 1983-2005 


\section{Figure 3: Distribution of Workplace Needs}

Panel A: BWRPS needs scalar $($ mean $=0.156$; variance $=0.030)$

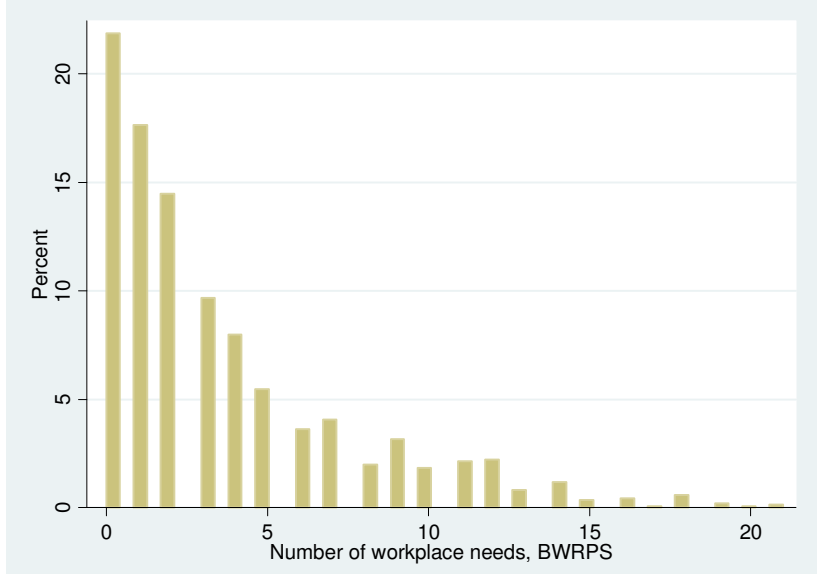

Panel B: WERS needs scalar $($ mean $=0.211$; variance $=0.057)$

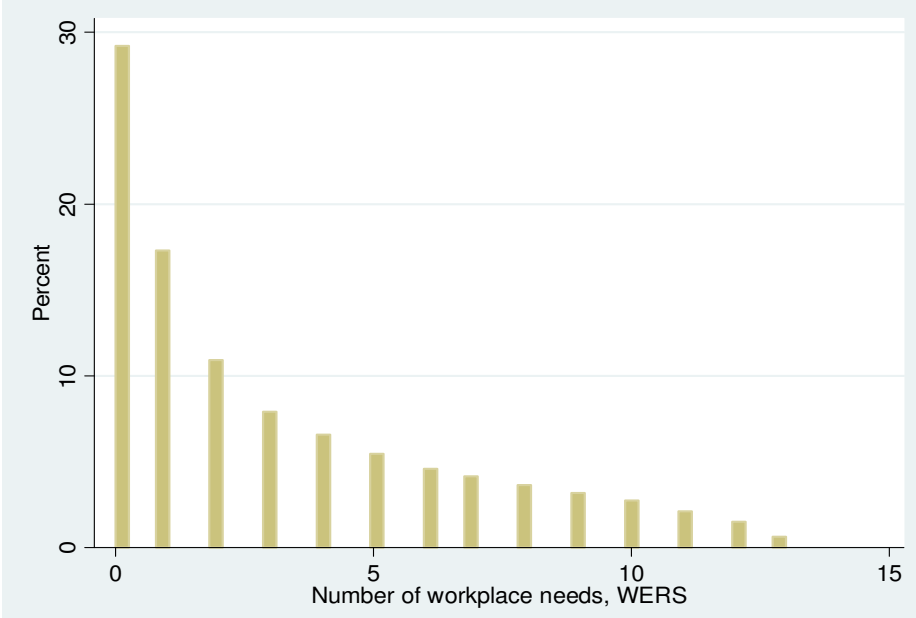

Panel C: WRPS needs scalar $($ mean $=0.34 ;$ variance $=0.022)$

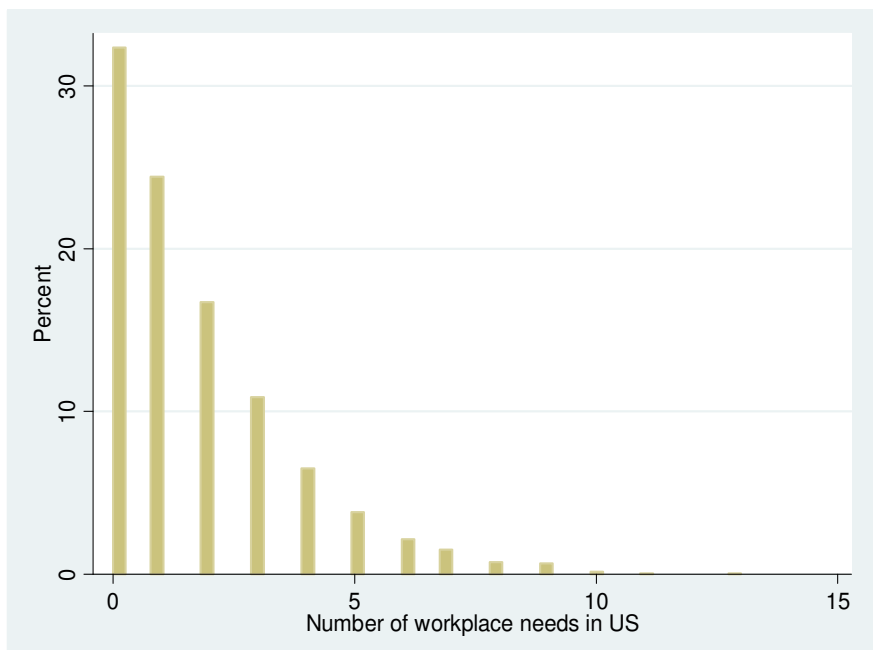




\section{Appendix A: The Data sets}

\section{UK: The Workplace Employee Relations Survey 1998}

The Workplace Employee Relations Survey 1998 (WERS98) is a nationally representative survey of workplaces with 10 or more employees covering all sectors of the economy except agriculture, fishing, mining and quarrying, private households, and extra-territorial organizations. The analyses use two elements of the survey. The first is the management interview, conducted face-to-face with the most senior workplace manager responsible for employee relations. Interviews were conducted in 2191 workplaces with a response rate of 80 per cent. The second element is the survey of employees within workplaces where a management interview was obtained. Self-completion questionnaires were distributed to a simple random sample of 25 employees (or all employees in workplaces with 10-24) in the 1880 cases where management permitted it. ${ }^{25}$ Of the 44,283 questionnaires distributed, 28,237 (64 per cent) usable ones were returned. ${ }^{26}$

\section{UK: British Worker Representation and Participation Survey (BWRPS) 2001}

The BWRPS was conducted as part of the monthly BMRB Access Omnibus survey. Interviews were conducted using face-to-face computer assisted personal interviewing (CAPI) techniques. In total, some 3614 interviews were conducted as part of the Omnibus survey. Of these 1,355 people were eligible to take part in the BWRPS. The weighting schema used in this analysis ensures that demographic profiles match those for all employees in Great Britain aged 15 or over.

\section{US: Worker Representation and Participation Survey (WRPS) 1994-1995}

The WRPS was based on telephone interviews with a nationally representative sample of 2,408 adults, 18 and over, who were employed in private companies or nonprofit organizations in the continental US with 25 or more employees.

\section{US: Peter Hart Opinion Poll Data}

Peter D. Hart Research Associates has conducted random telephone calls for the AFL-CIO on worker attitudes toward unions and economic issues. It has used the same question about voting for a union in all of its surveys, which gives it the best time series of worker preferences available.

\footnotetext{
${ }^{25}$ The probability of worker selection is the product of the probability of the workplace being selected and the probability of an employee being selected from within that workplace.

${ }^{26}$ The weighting scheme compensates for sample non-response bias detected in the employee survey (Airey et al., 1999: 91-92).
} 


\section{Appendix B: Needs Scales}

There are a variety of ways in which one might wish to construct an index of the 'needs' or 'problems' workers face at the workplace. Traditionally, analysts have contented themselves with a single measure, such as an overall job satisfaction measure or perception of the climate of employment relations. However, single measures suffer from a number of drawbacks. First, any single item will only capture a part of an underlying multi-dimensional concept such as 'needs' or 'problems' at work. Measuring such a concept across various dimensions helps reduce the degree to which a proxy for needs suffers from this type of measurement error. Second, there is no reason, a priori, why one should give precedence to one facet of workplace needs or problems. Third, particular needs or problems fall or rise in salience depending on external factors, such as the point in the business cycle. For instance, workers may be less likely to cite problems with pay satisfaction when the labor market is tight and employers are having to meet fairly large wage demands to attract and retain workers. A multi-item index can 'smooth' such problems so giving a potentially more accurate measure of changes in needs over time. Another big advantage of a multi-item scale scored as a fraction of the total possible number of problems or needs recorded is that it offers a possibility of making comparisons across surveys where the specific survey questions are not identical.

Having chosen a multi-item scale, one needs to consider what enters the scale and how items should be added together. We were constrained in the items available to us since the surveys had already been undertaken. Fortunately those for both the USA and the UK contained items relating to key domains, notably the climate at the workplace, 'gaps' in influence between what workers had and what they wanted, satisfaction with various aspects of their jobs, ratings of management, and so on. We chose to record a need or problem each time a respondent expressed one. As indicated in the text, results were not sensitive to whether we used the full distribution of answers to a particular item, or simply entered it as a dummy $(0,1)$ variable where $1=$ a problem or need. One might consider giving greater weight to some items than others in an additive scale, but there were no a priori reasons for doing so. Inter-item correlations were generally positive suggesting adding items together was not an unreasonable strategy. The Cronbach alpha for all items in the BWRPS was .80 , while the alpha for those in WRPS was .64.

There are difficulties running principal components analyses on the items entering the scales because, as explained in the text, some questions were randomly assigned to sub-samples.

Consequently, whereas one can readily add up scores to similar questions to form a scale, principal components analyses would have to be run on the sub-samples asked the same set of questions.

To test the effect of a single item measure relative to the needs scale we took measures of employment relations climate in the UK and the US. We reran Table 5 columns 1 and 2 replacing the needs fraction with measures of climate. In the case of the UK, we used responses to the question: 'how would you rate relations between employees and management at your workplace?' with highest score being 'excellent' then 'good', 'only fair' then 'poor'. Scoring 'poor' as the highest and 'good' as the lowest, the coefficient was 0.52 with a t-stat of 6.38 . Whilst strong this coefficient compares to $3.77(t=9.42)$ for needs. For US non-union workers we used responses to the question 'do you think relations between employees and management at your organization are better than average, worse than average or about the same as in other places?', coding 'worse' as 1 otherwise zero. Again, while strong $(0.67, t=5.04)$ it compares to a coefficient of 2.45 at $t=9.31$ for needs. On the basis of this test, the needs effects are much larger than those of single items. 
The needs scales were constructed using the following items:

\begin{tabular}{|c|c|c|}
\hline BWRPS, 2001 needs scale, 0 to 23 & WRPS, 1995 needs scale, 0 to 13 & $\begin{array}{l}\text { WERS, } 1998 \text { needs scale, } 0 \\
\text { to } 13\end{array}$ \\
\hline 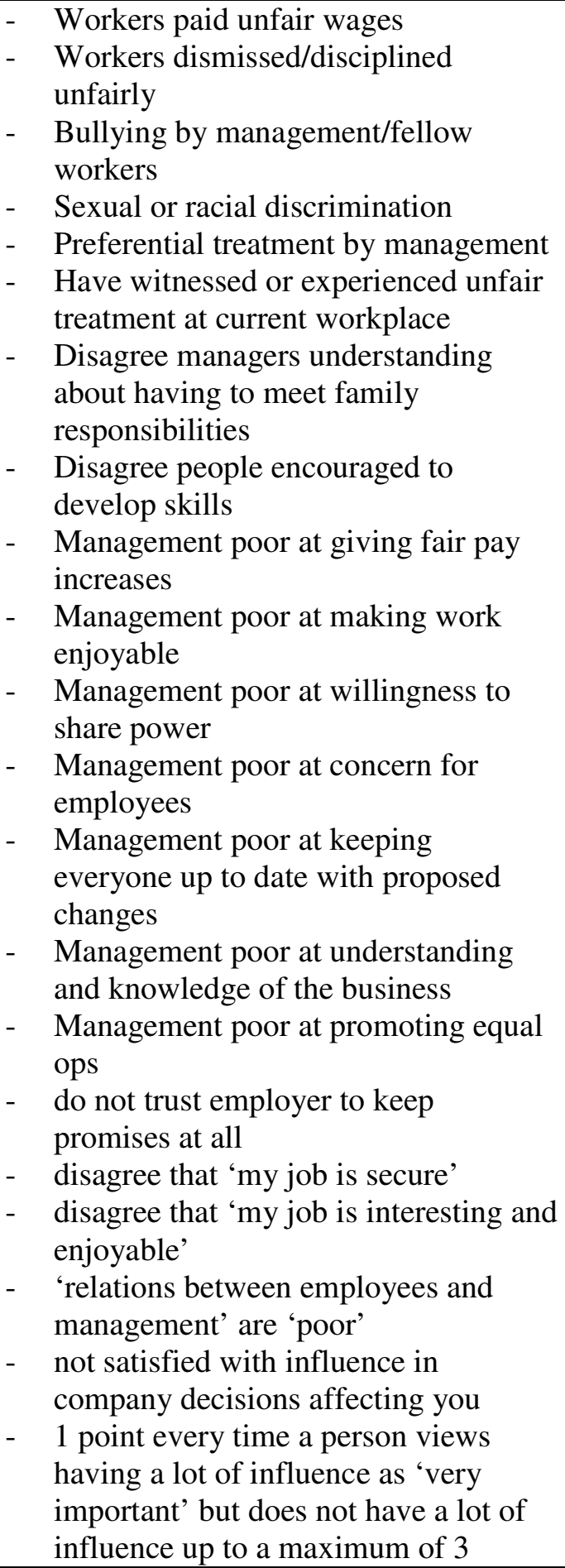 & $\begin{array}{l}\text { - don't trust management 'at all' to } \\
\text { keep promises } \\
\text { - relations between employees and } \\
\text { management poor } \\
\text { - relations between employees and } \\
\text { management worse than average } \\
\text { - not at all satisfied with influence in } \\
\text { company decisions affecting job or } \\
\text { work life } \\
\text { - not at all likely to get influence you } \\
\text { want if you tried } \\
\text { - management never take } \\
\text { suggestions seriously } \\
\text { - have held back from making } \\
\text { suggestions about how to work more } \\
\text { efficiently through fear of own or } \\
\text { someone else's job } \\
\text { - company system for resolving } \\
\text { problems of individual employees is } \\
\text { 'not effective at all' } \\
\text { - 'town' meetings not effective at all } \\
\text { in resolving group problems } \\
\text { - open door policy not effective at } \\
\text { all in resolving group problems } \\
\text { - employee committee not effective } \\
\text { at all in resolving group problems } \\
\text { - } 1 \text { point every time a person views } \\
\text { having a lot of influence as 'very } \\
\text { important' but does not have a lot of } \\
\text { influence up to a maximum of } 4 \text { or } \\
\text { (depending on random routing) } 1 \\
\text { point every time a person is not } \\
\text { satisfied with influence on these } \\
\text { items }\end{array}$ & 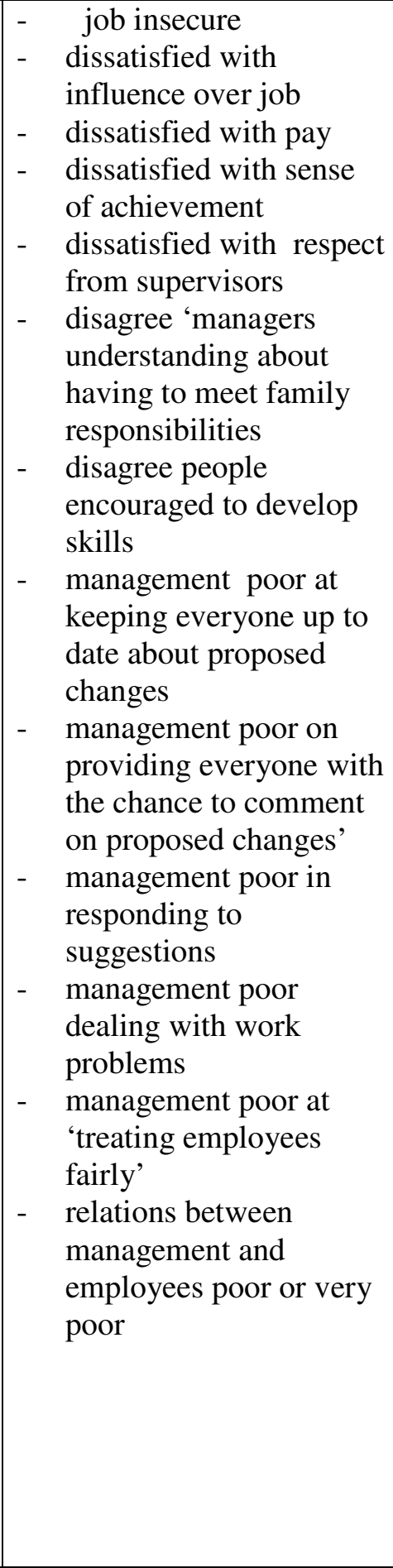 \\
\hline
\end{tabular}


Appendix C: desire for union representation $(0,6)$ among non-members by needs

\begin{tabular}{|c|c|c|c|c|c|c|}
\hline & \multicolumn{3}{|c|}{ High Needs } & \multicolumn{3}{|c|}{ Medium/low needs } \\
\hline & Pooled & USA & UK & Pooled & USA & UK \\
\hline \multicolumn{7}{|l|}{$\begin{array}{l}\text { Management } \\
\text { attitudes (ref: } \\
\text { neutral) }\end{array}$} \\
\hline \multirow[t]{2}{*}{ Opposed } & 0.700 & 0.395 & 1.408 & 0.334 & 0.382 & 0.160 \\
\hline & $(5.78)^{\star \star}$ & $(2.89)^{* \star}$ & $(4.98)^{* \star}$ & $(4.09)^{\star \star}$ & $(4.26)^{\star \star}$ & $(0.86)$ \\
\hline \multirow{2}{*}{ In favour } & 0.886 & 0.622 & 1.310 & 0.836 & 0.685 & 0.790 \\
\hline & $(3.59)^{\star \star}$ & $(1.62)$ & $(3.36)^{* \star}$ & $(5.93)^{\star \star}$ & $(3.17)^{\star \star}$ & $(3.91)^{\star \star}$ \\
\hline \multirow[t]{2}{*}{ Constant } & 1.827 & 2.516 & 0.840 & 0.919 & 1.655 & -0.142 \\
\hline & $(4.50)^{\star *}$ & $(5.59)^{\star *}$ & $(0.92)$ & $(3.29)^{\star *}$ & $(5.14)^{\star *}$ & $(0.27)$ \\
\hline Observations & 1021 & 748 & 273 & 1635 & 1019 & 616 \\
\hline R-squared & 0.12 & 0.13 & 0.29 & 0.11 & 0.13 & 0.17 \\
\hline
\end{tabular}

Controls are as per notes in Table 2 plus the count of HRM practices and the USA dummy in the pooled regression

\section{Appendix D: desire for union representation $(0,3)$ among non-members in non-unionised workplaces, WERS, linear estimation}

\begin{tabular}{|l|l|l|}
\hline & $(1)$ & $(2)$ Fixed effects \\
\hline Needs & 0.245 & 0.193 \\
\hline Count of HR policies & $(3.08)^{* *}$ & $(2.24)^{*}$ \\
\hline & 0.052 & \\
\hline $\begin{array}{l}\text { Count of variable pay } \\
\text { schemes }\end{array}$ & $(3.32)^{* *}$ & \\
\hline & -0.028 & \\
\hline $\begin{array}{l}\text { Management attitudes to } \\
\text { union (ref: neutral) }\end{array}$ & $(1.40)$ & \\
\hline In favour & & \\
\hline & 0.242 & 0.120 \\
\hline Opposed & $(4.61)^{* *}$ & $(2.25)^{*}$ \\
\hline & 0.047 & 0.078 \\
\hline Don't know & $(0.92)$ & $(1.43)$ \\
\hline & -0.194 & 0.014 \\
\hline Constant & $(0.57)$ & $(0.05)$ \\
\hline & 0.417 & 0.941 \\
\hline Observations & $(3.23)^{* *}$ & $(8.17)^{\star *}$ \\
\hline R-squared & 5482 & 5708 \\
\hline
\end{tabular}

Notes: (1) controls common to both models: female, age (6 dummies), ethnicity, health problems, marital status, qualifications ( 7 dummies), occupation ( 9 dummies), workplace tenure (4 dummies), hours (5 dummies), gender segregation in the job at the workplace ( 5 dummies), banded wages (11 dummies), permanent contract. Additional controls in model (1) which excludes fixed effects: region (11 dummies), local area unemployment, establishment size, independent single establishment, industry (12 dummies), workplace age, foreign owned, \% female no part-timers, no ethnic minorities. (2) The count of HR policies runs from 0 to 6 with a point scored every time the following are present: regular meetings between senior management and the whole workforce; team briefings involving two-way communication; quality circles; grievance procedure; joint consultative committee; HR specialist. The count of variable pay schemes runs from 0 to 4 with a point scored every time the following are present: profit-related pay, ESOPs, performance-related pay, cash bonuses. 